\section{LECTURES ON THE THYROID}

By J. H. Means, M.D. Pp. viii + II3, illustrated. London: Geoffrey Cumberlege, Oxford University Press. 1954. 24s.

This book is written by a well-known authority on thyroid function who, before his retirement from active participation in the work at the Thyroid Clinic of the Massachusetts General Hospital, had contributed greatly to the advancement of knowledge on this aspect of endocrine disease.

These lectures deal briefly with the integration of endocrine function, the formation and structure of the thyroid hormone, the use of hormones, drugs and radiation in treatment. The fourth lecture is an interesting discussion by the author on the perplexing problem of the aetiology of Graves' disease. Finally the fifth lecture on the need for iodine concludes the series.

Written essentially for lecture-audiences, the material touches briefly on some of the still unsolved problems of thyroid function. It correlates the adaptation syndrome of Selye with some of the mechanisms of thyroid disease.

The problem of the functioning and nonfunctioning adenoma is discussed. The author, having found a malignant nodule in a thyroid gland of a patient suffering from $\mathrm{Gr}$ aves' disease, who had been treated with radioiodine, agrees that nodular goitres should be treated by surgical measures.

Much emphasis is placed on the involvement of lymphoid tissue in Graves' disease and that 'lymphoid high lights keep appearing first in one place and then in another in the overall picture.'

This interesting and well-written collection of five lectures on various aspects of thyroid function is well worth perusal by all those interested in $\stackrel{0}{0}$ thyroid disease.

T.L.

\section{PULMONARY CIRCULATION• AND RESPIRATORY FUNCTION}

A symposium held at Queen's College, Dundee. Pp. 44, illustrated. Edinburgh : E. \& S. Livingstone Ltd. I956. I2s. 6d.

This slim volume contains the collected papers and discussions of a group of medical men whose prime interest lies in the lungs-it is the record of a conference on applied pulmonary physiology held at the University of St. Andrews in September 1955. It contains a great deal of information but the main purpose of this publication will be to stimulate interest in a subject which only recently has had attention paid to it ; a subject which must interest all concerned with the treatment of chest diseases. Investigative procedures that are designed to elucidate the intricacies of pulmonary haemodynamics and pulmonary gas exchanges appear extremely complicated to the practising clinician. Higher mathematics there must be; the translation of variables of a natural phenomenon into figures which must then be equated with clinical states is a concept which is no longer futuristic. How now to act for the patient's good is not yet established, time and further work will tell us.

This little book does well to outline what the क leaders in this field are doing and thinking. Furthero more the balance between calculus and clinic judgement is stressed in a particularly sensibje. communication from Dr. Robert Coope. This book is recommended.

\title{
BACK NUMBERS OF THE POSTGRADUATE MEDICAL JOURNAL
}

\begin{abstract}
If any subscribers have copies, in good condition, of MARCH and APRIL 1952, the Fellowship of Postgraduate Medicine, 60 Portland Place, London, W.r, will be glad to purchase them.
\end{abstract}

\section{NOTICE OF SPECIAL INTEREST TO SUBSCRIBERS: \\ "WHY NOT HAVE YOUR COPIES OF THIS JOURNAL BOUND INTO YEARLY VOLUMES?"}

\begin{abstract}
Arrangements have now been made to have the twelve monthly issues fully bound in dark green pin head cloth. lettered in gilt on spine with name of Journal, Volume Number and year, complete with index at front, 19s. 6d. per Volume, post free. A limited number of out of print journals are available to bind into volumes and make your library complete. Price on application giving details of issues required to complete back volumes.
\end{abstract}

TH: FELLOWSHIP OF POSTGRADUATE 60 PORTLAND PLACE, LONDON, W.I

MEDICINE

\section{WHY NOT HAVE YOUR JOURNALS BOUND?}

